\title{
CONSEQUENCE OF LACK OF WORK SAFETY MANAGEMENT IN SMALL CONSTRUCTORS COMPANIES IN THE CITY OF PRESIDENTE FIGUEIREDO
}

\author{
Sinndy Rossaly Cabral de Oliveira ${ }^{1}$, David Barbosa de Alencar ${ }^{2}$, Ana Caroline da Silva \\ Taumaturgo ${ }^{3}$, Marto Gibran Andrade Silva ${ }^{4}$, Camily Murrieta Vasconcelos Oliveira Bezerra ${ }^{5}$ and \\ Manoel Henrique Reis Nascimento ${ }^{6}$
}

\author{
1, 2,3,4 Braulo Cardoso de Mattos Higher Education Institute - FASERRA. Manaus-Amazonas, Brazil. \\ ${ }^{5}$ Nilton Lins University. Manaus-Amazonas, Brazil. \\ ${ }^{6}$ Galileo Institute of Technology and Education of the Amazon - ITEGAM. Manaus-Amazonas, Brazil.
}

Email: srossaly@gmail.com, david002870@hotmail.com, caroline.taumaturgo@gmail.com, marto_as@ hotmail.com, camilymc@hotmail.com, hreys@itegam.org.br

Received: Aug 29th, 2019

Accepted: Aug 30th, 2019

Published: December 02 ${ }^{\text {th }}, 2019$

Copyright (C2016 by authors and Galileo Institute of Technology and Education of the Amazon (ITEGAM).

This work is licensed under the Creative Commons Attribution International License (CC BY 4.0).

https://creativecommons.org/licen ses/by/4.0/

\section{Opea Aceces:}

\section{INTRODUTION}

The civil industry in Brazil is still closely linked to labor, workers in this area play a fundamental role, but many of them still suffer from the negligence of everyday life, and end up being disobedient, inattentive or even disinterested by the practices of safety. However, according to [1] they are deprived of the correct teaching, as well as materials, or even of good conditions necessary to carry them out, being in some cases a cultural problem, caused as indicated by studies such as insufficient planning and in some cases. cases the lack thereof.

Although [2] establishes the administrative conduct, planning and organization, as well as the health and safety conditions of workers, providing the creation of a safe flowerbed. It, like the other standards, does not ensure productivity or good management, making it necessary to adjust bibliographic guidelines to pre-established logical guidance.

In general, it is noticeable that site planning has still been viewed in the wrong way, it must be an essential part of site management, although it is seen as an isolated part, it is necessary to integrate the hierarchical levels of planning, especially due to constant programming changes and the distance between headquarters [3]. Another factor linked to this is that it has been learned to perform the activity only empirically, something rudimentary as trial and error over the years, by managers [4]. In his work [5] he analogously notes the absence of method, and that common sense and experience are most used.

The development of the method or any planning of this area involves the analysis of enterprise data, such as its logistics, as well as the logical sequence of construction and how financial resources can be used at a given time [6]. In his work [7] confirms by stating that the logistics of temporary facilities, security, material handling and storage system, should involve the physical arrangement of workers, materials, equipment, work areas and storage.

But it is important to know that when talking about the physical arrangement of workers, they are talking about their management. [8] defines as the set of integrated decisions about 
employment relationships that influence the effectiveness of employees and organizations.

It is also clear that there must be implementation through the organization of information in computational tools, low cost software that enables the association and description of costs and tasks, as well as the time they should be performed, making the analysis easy to distribute. of resources [9].

\section{BIBLIOGRAPHIC REFERENCE}

For a better understanding of the subject to be addressed it is necessary to delve into the topics related to the research content, thus clarifying any doubts about the topic addressed..

\section{II.1 OBJECTIVES AND PRINCIPLES OF OCCUPATIONAL SAFETY}

Occupational Safety is nothing more than the union of science and technology, with the aim of preventing and protecting employees in their workplace, seeking to reduce and prevent occupational accidents.

The main objective of occupational safety is to ensure that work activities are carried out more safely, occurring without danger to workers, to reduce risks, to analyze the factors that may lead employees to suffer accidents and to generate occupational diseases over time.

By understanding what occupational safety is all about, we can analyze safety management in a more practical way and better understand the union and results of these tools.

According to [10], the work accident has negative points in all areas, be they human, social and economic aspects. Also according to [11], accidents will only be really avoided, when the causes are given real importance and generate them, this analysis is in-depth studies of how the risks arise, and only then will start a survey of preventive measures that prevent or at least reduce the high rates of accidents and occupational diseases. With the awareness of the companies, the proper training of them and their employees, and a good planning of the working environment conditions, the tendency of these numbers is to decrease.

By understanding what occupational safety is all about, we can analyze safety management in a more practical way and better understand the union and results of these tools.

\section{II.2 NR 18 .}

A few years ago, with the considerable increase in work accidents, and the poor working conditions that many employees were undergoing, reaching high levels of loss of life due to lack of control and supervision of the beds, the authorities began to intensify their work. concern with this cause, where it was decided to establish administrative guidelines, which aims to control and create preventive safety systems, in working conditions, in the environment that the individual acts, in order to reduce the accident rates and occupational diseases, the government created the occupational health and safety regulations (NR) on June 8, 1978, through Ordinance No. 3,214 [10].

With the inclusion of the NR 18 guidelines and the Construction Industry Working Conditions and Environment Program, it was believed that it would reduce accidents and give a new face to this much-asked subject. But the difficulties in applying the norm are still great, because there is a lack of knowledge of the agents involved, within the construction companies and construction industries, as well as not an active supervision in the fulfillment of the same, leaving to be desired in the effectiveness of it.

\section{II.2.1 NEW FROM NR 18.}

- The purpose of the new version of NR 18 is expressed in item 18.1.1 $" \ldots \ldots$ to establish administrative, organizational planning guidelines that aim at the implementation of control measures and preventive safety systems in the processes, conditions and in the Work Environment in the Construction Industry "[12], these changes seek to address issues not previously mentioned in NR. [12] comments on some changes:

- $\quad$ The creation of committees, in order to generate more participation from all stakeholders, was created the CPN and CPR (National and Regional Standing Committees), and its purpose is to evaluate, amend and fight for the updating of the standard.

- $\quad$ In some countries, there is a code of practice that seeks to create means to facilitate compliance with the rules contained therein. To this end, RTP (Technical Procedural Recommendations) has been created to find ways to show that compliance is not impossible. of the norm.

\section{MATERIAL AND METHODS}

The research was divided into three stages: literature review, data collection and data analysis. Firstly, a bibliographic review was conducted to guide data collection and analysis. Soon after, a city of Amazonas was chosen to be applied to the study. To support the content, a checklist was prepared, it was applied and recorded with the photographic report. With the results obtained, the results were analyzed and the most relevant items were classified, taking into consideration the region and its constructive peculiarities. Results were discussed, data were tabulated in the graphs and the research conclusions were concluded.

\section{III.1 DATA COLLECT}

\section{III.1.1. SELECTION OF MUNICIPALITIES AND COMPANIES INVOLVED IN THE RESEARCH.}

By defining this study, it was understood that for a better initial explanation, it would be necessary to focus on only one Municipality, as we are from the Northern region and we want to understand how these tools can help us improve the results in our region, and for Logistics issues, the chosen municipality was, Presidente Figueiredo, located in the interior of the Amazon, 107 $\mathrm{km}$ away from the capital. For the selection of the companies we could not put up the garments, because currently the municipality has very few companies operating in the field of construction, but we sought the builders who welcomed us and accepted the invitation to participate in the study. We will apply the analysis to two separate engineering companies, small businesses, with variations of 25 employees per site.

\section{STUDY APPLICATION}

\section{IV.1 PREPARATION OF THE CHECKLIST.}

After a cursory analysis in the flowerbeds, we selected the checklist as a study tool. It was chosen because it is easy to analyze and allows us a broad source of information in the short term.

To build the first version of the checklist, it was necessary to perform an analysis on NR18 standard in order to identify 
criteria to be followed in the application of the tool. The criteria analyzed were:

The points addressed were those that could be identified in just one visit to the site, seeking a centralized and directed observation, taking into account the compliance with the NR18 topics. So some items were not entered in the checklist.

With the definition of items that would be part of the list, it is now for the next step, using the same parameters as [13], adopted in the definition of guidelines, ie, for each item presented would have three options to be chosen "YES" , "NO" and "NOT APPLICABLE". Answers that are "YES" portray the good qualities of the flowerbed, always based on NR 18, the answers presented as "NO" refer to the non-compliance with the guidelines presented in the standard, while those selected as "NOT APPLICABLE" implies that this item It is not mandatory because the jobsite stage does not meet the standard requirements, so it is not up to the jobsite to be evaluated.

As shown in Table 1, the checklist excerpts are presented in a practical way, with a current language, seeking to simplify and obtain a more accurate result.

Table 1: Excerpt from the checklist.

\begin{tabular}{|c|c|c|c|}
\hline $\begin{array}{c}\text { ORDER AND } \\
\text { CLEANING }\end{array}$ & YES & NO & $\begin{array}{c}\text { NOT } \\
\text { APPLICABLE }\end{array}$ \\
\hline $\begin{array}{c}\text { - The site is clean, } \\
\text { without spreading, so } \\
\text { that the safety and } \\
\text { movement of } \\
\text { materials and people }\end{array}$ & & & \\
are not compromised. & & & \\
\hline - The rubble has a & & & \\
specific deposit site \\
(delimited site); \\
- The rubble is \\
transported to ground \\
floor by closed trough \\
(truck).
\end{tabular}

Source: Authors, (2019).

At the end of each topic on the list was left a space for notes to analyze the observations of the members of the site.

\section{IV.1 CHECKLIST APPLICATION AND PHOTOGRAPHIC RECORD}

After defining the companies that participated in the study and the checklist items, the application started, each verification lasted approximately one hour, because an initial visit was already made, when the first contact was made, the collaborators were more comfortable with our presence.

It was observed that items such as, for example, place of meals had, but not in their entirety as predicted by the norm, and as the list requested the length according to NR 18, we chose to only classify as "YES" the item with all elements attended.

Initially there was a request inviting companies to participate in the survey, but it was not advised the exact day that would occur to avoid any data manipulation, for example, tidying up the site and distributing the PPE, just for the visit.

During the visit, we recorded some images, in order to enrich the research and generate a photographic report. Some points were selected in particular to be observed and recorded.

Figure 1 shows us the site conditions in a hardware area where activities analyzed by NR 18 are developed.

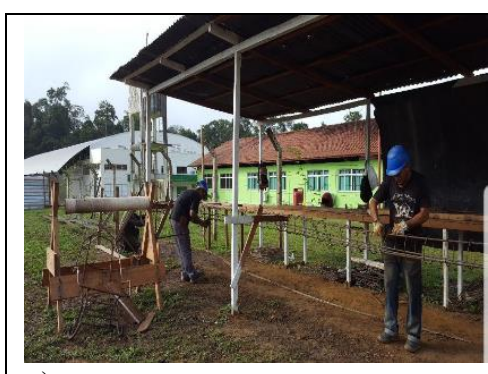

a)

Figure 1: Area, destined to hardware and policing machine. Source: Authors, (2019).

Figure 2 allows us to make a comparison of the sanitary facilities of both companies, clearly showing the difficulties faced by professionals from the municipality.

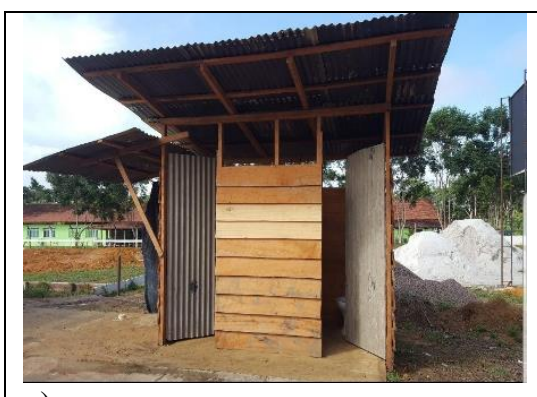

a)

Figure 2: Bathroom, company sanitary facilities. Source: Authors, (2019).

The images, therefore, show the practices and behaviors adopted by companies, which sometimes escape the requirements and adjustments of NR18, bringing disruptions to the health and safety of employees.

\section{IV.2 DATA TABULATION}

At this stage, we deal only with the data obtained in the research. The scoring method followed was [13], the final result of a flowerbed, in a given item or topic, matches the ratio between the total number of "YES" items and the total points achieved. (Summing "YES" with "NO") multiplies the result by ten and gets the final grade, ranging from 0 to ten.

\section{$\mathrm{N}_{\mathrm{nr} 18}=$ "SIM" x 10 / ("YES" + "NO") \\ Figure 3: NR 18 compliance calculation formula. Source: Authors, (2019).}

This method of data tabulation is able to evaluate in general and divided by topics or items, providing a complete analysis of the results throughout the research.

The flowerbed behavior indicator can be obtained through the tabulation result, but this grade cannot be classified as the only quality and safety variable of the flowerbed, as there are several other points to be studied and evaluated.

\section{RESULTS AND DISCUSSION}

At this stage we achieved the results and analyzed the information obtained through the lists applied, the visits made and the support of the photographic report. 


\section{V.1 ANALYSIS OF RESULTS}

The objective of the research is to guide a profile for the construction companies of the city of Presidente Figueiredo, analyzing if they comply with the provisions of NR 18 . To this end we highlight the analysis and diagnosis of compliance with NR, we also seek to understand why the non-compliance by parts of companies.
The data obtained indicate a median condition where some points are executed, but not in their entirety and others of paramount importance such as signaling, fire fighting and protection platform does not exist, leaving something to be desired in safety items.

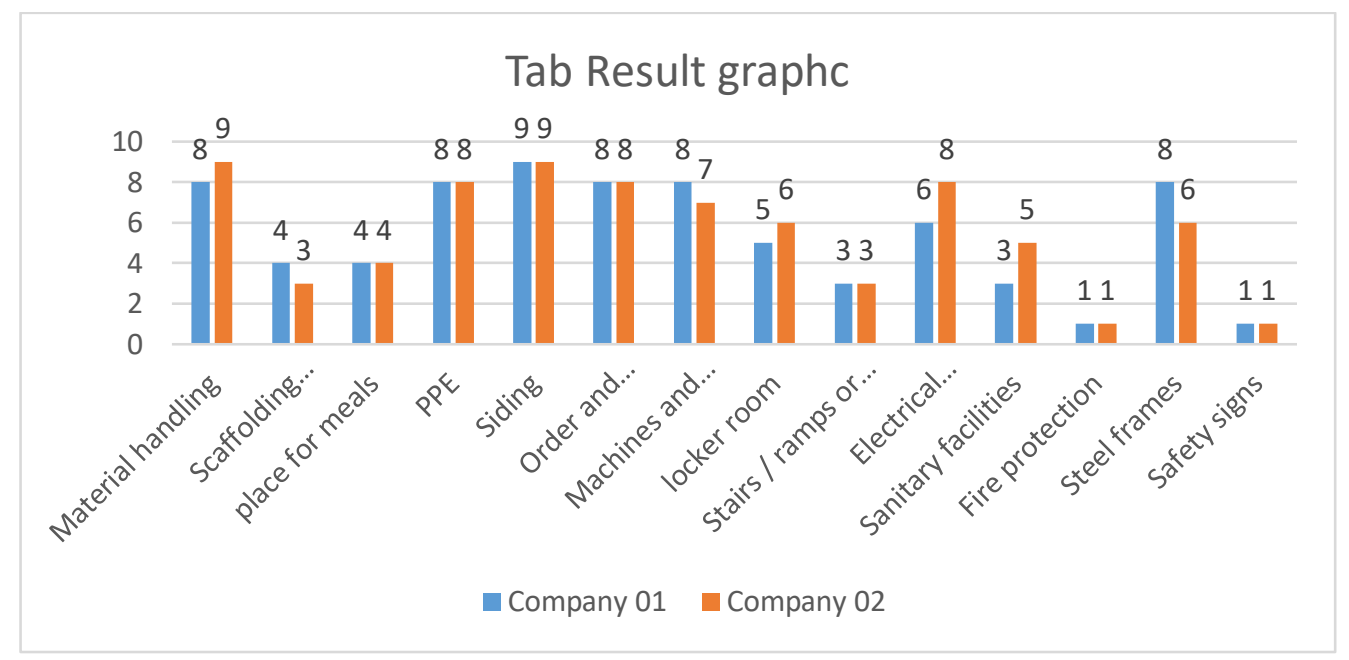

Figure 4: NR 18 compliance chart result list. Source: Authors, (2019).

By comparing notes and analyzing the results, we will explain the need for the negligence presented by each company:

- Material storage: for companies this item is essential as it ensures the safety of the purchased material, and the care for loss and consequently loss of profit, both companies take care of this item and obtained maximum marks.

- Suspended scaffolding: Both companies use scaffolding with heights ranging from $8 \mathrm{~m}$ to $10 \mathrm{~m}$, we found that they do not support this item, because the fact of having the material does not suffice if it has irregularities and lack of training, NR 35 advises on the training of employees in high-level services, but the companies in question do not comply with this item, their grades did not reset because there are scaffolding and seat belts but there are still items that need to be reviewed and adjusted..

- Meal location: this point is evidenced in NR 18, but in the companies interviewed, employees enjoy two hours of lunch, since both do not offer lunch, there is a clean area with very few chairs (in reality they are benches, apparently made by employees themselves), where those who bring their lunch, eat their meals, the ratings for this item is reasonably low, as it does not meet the standard requirements.

- PPE: Item of the utmost importance and apparently the most performed by the companies, we even concluded for them that the availability of PPE is already sufficient to guarantee the safety and comfort of their employees. high grades.

- Siding: Both companies use siding to protect their building areas, which is complied with according to the standard.

- Order and Cleanliness: On the day of the visit, the flowerbeds were clean and well organized, getting relevant grades.
- Machinery and Equipment: Both use machines such as; Makita, saw bench, concrete mixer and these equipments were all accompanied by safety elements as required by standard.

- Cloakroom: The available cloakrooms are a little out of the ordinary, well improvised and uncomfortable for employees, but we can not completely reset because they exist, but need repairs and adjustments.

- Stairs / ramps and walkways: an item not obeyed by the builders, the stairs were improvised and the ones being executed had no railing, leaving something to be desired in this requirement.

- Electrical installations: The item is obeyed by both builders, both need to adjust details such as wire passage and height, but existing installations do not endanger the safety of employees.

- Sanitary facilities: The two companies in question meet the requirements within their clear limitations, but still must seek improvements.

- Fire protection: a point of great relevance in any work, and this item is disregarded by both companies interviewed, not providing at least one extinguisher for an emergency, this item as a risk minimizer was discussed in the act. interview, and the two companies did not obtain any arguments.

- Safety signs: Another point neglected by the builders is safety signs, both sites do not have any signs, in breach of NR 18.

With the points analyzed and discussed, we move to the tabulation phase of the average of companies in each item, as the following graph presents. 


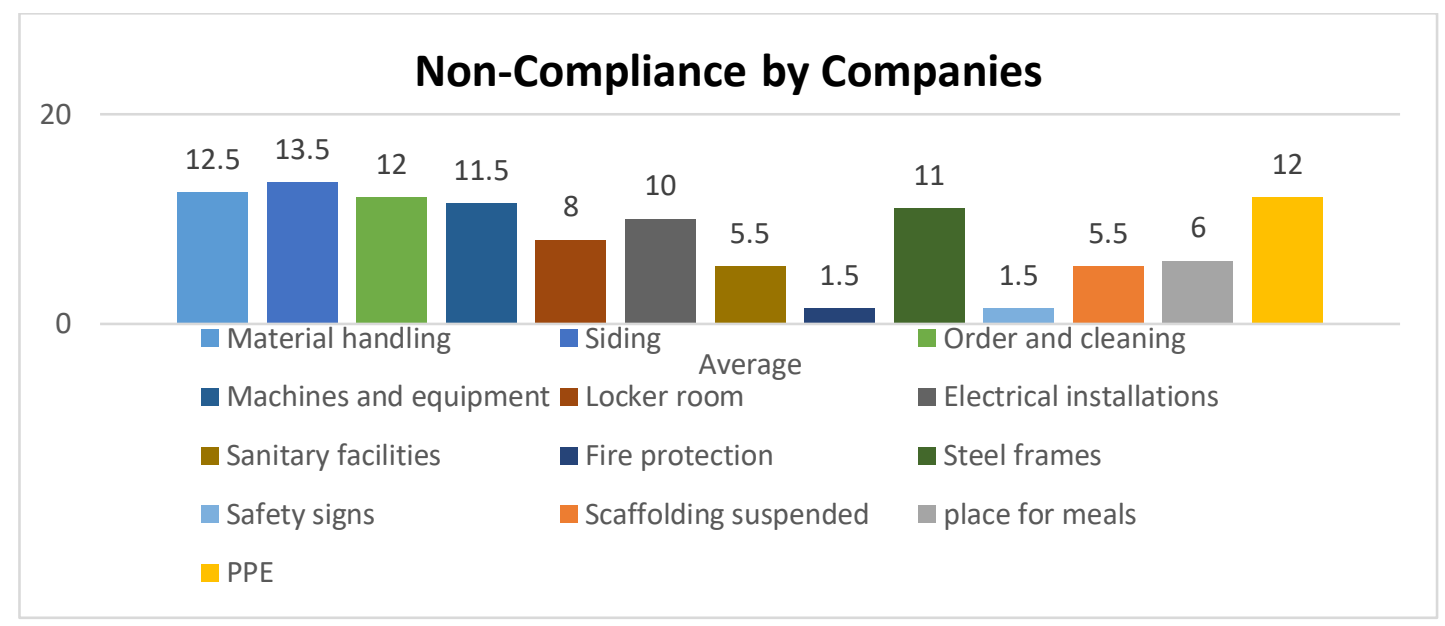

Figure 5: Graph, result of the average of the analyzed companies.

Source: Authors, (2019).

Finally, the results presented express the degree of noncompliance of the companies in accordance with the norm, leading the companies to obtain a lower than average tabulation grade.

\section{FINAL CONSIDERATIONS}

The study aimed to simply and practically present the results obtained, the fact that there are few construction companies operating in the city did not contribute to obtain more accurate results.

Finally, it is concluded that there is a need for development in the workplace, it is believed that the lack of information about NR 18 contributes to such mismatches, factors such as lack of supervision, lack of knowledge of professionals ahead of construction companies. lead to the permanence of this picture of neglect.

Another observation with the development of the work is that there is a lack of a work safety model to be followed by the builders, because the fact of delivering some PPE, if not investing in safety management does not minimize the risks, is to cover the sun with the sieve, Because the obvious risks remain present day by day, companies need to have the vision that money spent safely, is not waste but benefit to itself.

\section{SUGGESTIONS}

We suggest that further research be carried out in a year or two, believing that there will be more development, that the municipality seeks to invest in the construction market, because it generates local workability, income and dignity for its residents, and implement together the works secretariat is in compliance with NR 18, and there is a union of the private sector with the public in search of better working conditions.

\section{REFERENCES}

[1] Lins, Leonardo Melo, et al. Escassez de engenheiros no Brasil? Uma proposta de sistematização do debate. Novos estudos CEBRAP, 2014, 98: 43-67.

[2] NR, Norma Regulamentadora Ministério do Trabalho e Emprego. NR-18 - Condições e Meio Ambiente de Trabalho na Indústria da Construção. 2009.
[3] Laufer, A.; Tucker, R. Competence and Timing Dilemma in Construction Planning. Construction Management and Economics, London, 1988.

[4] Tommelein, I.D. Construction site layout using blackboard reasoning with layered knowledge. In: Allen, Robert H. (Ed.). Expert systems for civil engineers: knowledge representation. New York: ASCE, 1992.

[5] Rad, P.F. The layout of temporary construction facilities. Cost Engineering. 1983.

[6] Chay, K.W.; Anson, M.; Zhang, J.P.Implementation of visualization as planning and scheduling tool in construction. Building and Environment, Netherlands: Elsevier Science B.V., 2003.

[7] Frankenfeld, N. Produtividade. Rio de Janeiro: CNI, 1990.

[8] Chiavenato, Idalberto. Gestão de pessoas. $2^{\mathrm{a}}$ ed. RJ: Elsevier, 2005.

[9] Assumpção, J.F.P. Gerenciamento de Empreendimentos da Construção Civil: modelo para planejamento estratégico da produção de edifícios. 1996. Tese (Doutorado em Engenharia Civil) - Escola Politécnica, Universidade de São Paulo, São Paulo, 1996.

[10] Araújo, Nelma Mirian Chagas de Custo da Implantação do PCMAT na Ponta do Lápis. 1 ed. São Paulo: Fundacentro, 2002.

[11] Crispim, Lucas Vaz Franco. Avaliação: Análise Comparativa entre o Pcmat de uma Obra de Construção Civil de Criciúma-SC com a NR 18 - Estudo De Caso. 2011. 53 f. Trabalho de Conclusão de Curso (Graduação em Engenharia Civil) - Universidade do Extremo Sul Catarinense, Criciúma.

[12] Segurança e Medicina do Trabalho, 42 ed. São Paulo: Atlas, 1999. (Manuais de Legislação Atlas, 16).

[13] Saurin, T.A Método para diagnóstico e diretrizes para planejamento de canteiros de obras de edificaçãoes. Porto Alegre, 1997. 150 p.Dissertação de Mestrado em Engenharia (Civil) Universidade Federal do Rio Grande do Sul. 